\title{
Memoirs in Miniature: CM/1 Forms and Fragmentary Understandings of the Holocaust
}

\author{
Nathaniel Parker Weston \\ History Department, Seattle Central College, Seattle, WA 98122, USA; nate.weston@seattlecolleges.edu

\begin{abstract}
This article examines the Care and Maintenance $(\mathrm{CM} / 1)$ form of Paula Bettauer for what it reveals about her memories of surviving the Holocaust and her husband's murder in Auschwitz. The record includes a personal narrative, chronologies of her employment status and vital documents, as well as other details, all of which offer a view of navigating Vienna following the Nazi annexation and later deportation of the vast majority of the city's Jewish population. This article reports on these crucial pieces of information and analyzes various blank spaces in comprehending the Holocaust through an individual's postwar memories.
\end{abstract}

check for updates

Citation: Weston, Nathaniel Parker. 2021. Memoirs in Miniature: $\mathrm{CM} / 1$

Forms and Fragmentary

Understandings of the Holocaust.

Humanities 10: 22. https://doi.org/ 10.3390/h10010022

Received: 24 December 2020

Accepted: 25 January 2021

Published: 28 January 2021

Publisher's Note: MDPI stays neutral with regard to jurisdictional claims in published maps and institutional affiliations.

Copyright: (C) 2021 by the author. Licensee MDPI, Basel, Switzerland. This article is an open access article distributed under the terms and conditions of the Creative Commons Attribution (CC BY) license (https:// creativecommons.org/licenses/by/ $4.0 /)$.
Keywords: Nazi Vienna; antisemitism; Holocaust; $U$ Boot; survivor memoirs; Care and Maintenance $(\mathrm{CM} / 1)$ forms

\section{Introduction}

Between 1947 and 1952, thousands of Holocaust survivors in Austria, Italy, Switzerland, the United Kingdom, and West Germany completed Care and Maintenance (CM/1) forms, which documented their lives prior to, during, and following the war, sometimes briefly and other times at length. This allowed survivors to obtain status as Displaced Persons by the International Refugee Organization (IRO), making them eligible for material support and possible resettlement. The IRO oversaw Displaced Persons camps and urban centers and using information on the CM/1 forms as well as interviews, the agency determined if the refugees would receive assistance (Care and Maintenance Program 2019; Brown-Fleming 2016, p. 17). As memoirs in miniature, the forms provide key details about the Holocaust, but they also expose numerous gaps in understanding events. Created largely from survivors' memories, the information contained in these documents often remains fragmented and raises many questions that cannot be fully answered.

This article examines the CM/1 form of Paula Bettauer for what it reveals about her memories of surviving the Holocaust and her husband's murder in Auschwitz. Her story is exceptional because it illustrates the fate of part of the Bettauer family: her husband's father Hugo was the first victim of the National Socialists in Austria. This will be discussed at greater length below. Her CM/1 form includes a personal narrative, chronologies of her employment status and vital documents, as well as other details, all of which offer a view of navigating Vienna following the Nazi annexation and later deportation of the vast majority of the city's Jewish population. This article reports on these crucial pieces of information and analyzes various blank spaces in comprehending the Holocaust through an individual's postwar memories.

Other war refugees and victims of Nazi persecution, including former forced laborers and inmates of concentration camps, also completed CM/1 forms. These documents are available online through the archive of the International Tracing Service in Bad Arolsen, Germany. One must be prepared to sift through them to locate those filled out by Holocaust survivors, which frequently contain extraordinary details about individuals' lives. As Suzanne Brown-Fleming points out in her study of the International Tracing Service, CM/1 forms "are invaluable in reconstructing the experiences of individuals and families at 
the micro level" (Brown-Fleming 2016, p. 31). These microcosmic perspectives in turn point to specifics within larger structures of the Holocaust, such as Nazi persecution and extermination as well as Jewish people's on-going responses to them. Several scholars have recently begun to usefully employ CM/1 forms in their studies of Jewish people and others during and after the Second World War (Stone 2019; Borggräfe 2020; Chopard 2020; Huhn 2020; Panagiotidis 2020).

The personal statements and other information contained in the CM/1 forms do not constitute formal memoirs, but they are nonetheless based on survivors' memories in the years immediately after the war. They show people's lives prior to the arrival of the Nazi regime, which subsequently shattered them in different ways. The forms illustrate survivors' continued efforts at putting the pieces together again. In the introduction to the Encyclopedia of Holocaust Literature, the authors explain that the Holocaust memoir is not typical of the genre. They point out that it is not "a reflection on a life in the twilight of one's years," nor is it "the memory of a life called to mind in the tranquility of an armchair" (Patterson et al. 2002, p. xiv). Rather, the survivor's memoir, as David Patterson observes elsewhere, is rooted in recovery (Patterson 1998). The CM/1 forms reveal survivors' processes of recovery as works in progress.

This article first looks at Paula Bettauer's life leading up to the 1938 Nazi annexation of Austria. It then analyzes her memories of National Socialist rule. Finally, it examines the postwar period for how she began to recover her life. Ultimately, this article demonstrates that CM/1 forms can offer important insights about the Holocaust through the memories of individual survivors. It also shows that certain aspects of their experiences remain shrouded in the unknown, exposing gaps in understanding their stories. Sometimes these areas can be filled in with additional research and other times they cannot. Scholars therefore must continue to strive to unearth as much material as is available to gain the most complete portraits of survivors' lives possible. As memoirs in miniature, the CM/1 forms can assist with this and fulfill, in part, what Saul Friedländer argues about these types of sources in his comprehensive study of the Holocaust: "It is at this microlevel that the most basic and ongoing Jewish interaction with the forces acting in the implementation of the 'Final Solution' took place; it is at this microlevel that it mostly needs to be studied. And it is at this microlevel that documents abound" (Friedländer 2008, p. xx).

In general, literary responses to the Holocaust lend insight into aspects that would not be visible otherwise. The CM/1 forms, as memoirs in miniature, present a basic framework of the experiences of thousands of survivors, which illustrates that many details about the Holocaust remain unknown. Yet, these documents that include testimonies and chronicles of the lives of victims and deaths of their family members and others around them promise an abundance of individual stories and overwhelming evidence of the effects of Nazi discriminatory policies and genocide to future generations. Despite inherent challenges in reconstructing what survivors endured, using their $\mathrm{CM} / 1$ forms to compose biographies brings out a human side to victims' deep levels of being dehumanized.

\section{On Racial Grounds}

Frau Bettauer began the personal statement on her CM/1 form by pointing out that she had been "dismissed from her job on racial grounds upon the arrival of the Nazis." She had been employed as a state welfare insurance official since 1936, earning 500 Schillings per month, her employment history on the form shows (Bettauer 1950). At not yet 30 years old, this was a good position for a woman to obtain amid the Great Depression. The personal statement thus began with a memory of loss in the economic arena coupled with the Nazi annexation. National Socialism had been a formidable movement within Austria before 1938, launching an unsuccessful putsch in 1934, for instance, that nonetheless resulted in the death of Chancellor Engelbert Dollfuss (see, for example, Pauley 1992). It is unclear if Frau Bettauer had been affected by Nazism prior to 1938, however.

The CM/1 form indicates that she was born Paula Blum in Vienna in 1908. It also lists her birth certificate issued by the Jewish Community of Vienna (Israelitische Kultusgemeinde) 
among her vital documents. Just beneath it, noted parenthetically and in smaller script, the form states that she was baptized in December 1934 (Bettauer 1950). It does not include a baptismal certificate in the list of documents, but it could have been lost like numerous other personal effects during the Nazi era in Vienna. Nonetheless, her conversion presents an interesting perspective on her remark about being dismissed from her job on racial grounds in 1938. There are additional ambiguities surrounding her religious ancestry on the form elsewhere.

On the line where the applicant writes her religion, it shows the word "Jewish" (jüd.) struck through and replaced by "R.C." for Roman Catholic. Yet, later on the form, just above her personal statement, it notes "Austrian Jewish woman." (Oesterreicherin. Jüdin.) (Bettauer 1950). Indeed, she was both Jewish and Christian, but certain tensions seemed to surface between them that were not fully resolved. That she had been persecuted for her Jewish ancestry was a crucial aspect of her application, though she also appeared to wish that it be known that Catholicism was her confession of choice, asserting it on the form in the immediate postwar era as if in opposition to the Nazi project of racializing and essentializing her and others into an immutable category.

Prior to her baptism, Frau Bettauer attended primary school in Vienna during the years of the Great War, 1914 to 1918. The defeat of the Central Powers resulted in the dismantling of the Habsburg Empire and extreme economic hardship followed. She attended secondary school from 1918 to 1921 and trade school from 1921 to 1923, in the early years of the First Austrian Republic. It is unclear what took place in her life over the following decade. She was married in 1933 and as stated above, baptized the next year (Bettauer 1950).

If the baptism had been related to her marriage, then it seems more likely that it would have taken place beforehand. The failed Nazi coup in Austria could have motivated Frau Bettauer's conversion, in hopes that it would afford her greater protection than others of Jewish ancestry should National Socialism eventually take hold in the country. Notably, this was before the passage of the 1935 Nuremberg Laws, which did not consider baptism in determining the racial makeup of Jewish people. It is possible that her conversion was the product of a faith awakening. Her baptism also could have presented more social and economic opportunities for her in Austria, where antisemitism was widespread even before the Nazi annexation. Her employment history indicates that she worked at home from 1933 until obtaining her position as a state welfare insurance official in 1936 (Bettauer 1950).

Following her dismissal, the employment history attests that she endured several months of unemployment before she was able to find some odd jobs at significantly reduced wages, beginning in September 1939. She worked as a caregiver for nine months at 100 Schillings per month, before becoming an errand girl for the same wages. To this, she supplemented her income by working as a washerwoman, also for 100 Schillings per month (Bettauer 1950). In her study of Jewish people in Nazi Germany before the Second World War, Marion Kaplan shows that many Jewish women became the primary breadwinners in their households due to Jewish men's job losses (Kaplan 1998, p. 59). It is unclear if the same situation prevailed in Frau Bettauer's household, the CM/1 form does not indicate, but it is certainly possible.

Besides losing her job due to her Jewish ancestry, the form shows in the list of documents that she was issued a Jewish identity card in October 1939. These forms of identification were marked with an enormous letter J designating the racial status of Jewish people in Germany, Austria, and the annexed portion of Czechoslovakia, according to Nazi antisemitic policy. Frau Bettauer needed this ID card to travel through Vienna to and from her places of employment and elsewhere. It is not known if she was required to add Sara to her name, another antisemitic policy, this one targeting Jewish women specifically beginning in January 1939 (Jewish men had to add "Israel" to their names) (Friedländer 1997, p. 254). Obtaining the Jewish identity card was likely a necessary measure for her re-employment. It is dated the month immediately following the month when she began working again (Bettauer 1950). 
A peculiar item stands out in her employment history: namely, that she worked in October 1940 at the Sperlgasse "emigration camp" (Auswandererlager), as she described it (Bettauer 1950). This is odd because this was the name of an assembly camp (Sammellager) where Jewish people were deported from Vienna, but only beginning in 1941 (Moser 1992, p. 75). Prior to then, it was, in fact (and is again today), a school. Following the Nazi annexation, it became a school exclusively for Jewish children (Brosch 2012). It is possible that Frau Bettauer worked at the school and that she described it by what it would become later using a euphemism in calling it an emigration camp. It still seems strange that she did not refer to it as a school and that she would only work there for a month, but it may further illustrate the instability of regular employment for Jewish people under the Nazi regime.

A document, also from October 1940, shows that Frau Bettauer sought to leave Austria: it was an affidavit from New York (Bettauer 1950). As Ilana Fritz Offenberger writes in her study of Jewish people in Vienna under Nazi rule, "in order to register for a visa, one needed a financial guarantor in the USA to send an official written statement, an affidavit, to the consulate or the IKG [Israelitische Kultusgemeinde] on one's behalf" (Offenberger 2017, p. 137). By the following month, November 1940, Frau Bettauer was once again unemployed. It is not clear how or if this affected her ability to emigrate to the United States. Nonetheless, the list of documents also contains a booking certificate from Lisbon to New York dated 12 June 1941 issued by a travel agency in Leipzig, so obviously she took at least one additional step toward leaving the country (Bettauer 1950).

Another document points to the possibility that Frau Bettauer may have narrowly escaped deportation from Vienna. A discharge certificate from the Sperlgasse assembly camp dated October 1942 appears as the last item on the list of documents (Bettauer 1950). According to the Documentation Center of the Austrian Resistance (Dokumentationsarchiv des österreichischen Widerstandes n.d.), by October 1942, more than 48,000 Jewish people had been deported from Vienna (Breslauer 1924). The camp had ceased to function beginning in September (Moser 1992, p. 75), so combined with the information on the employment history, it is possible that she worked there in some capacity. This may have provided a certain amount of protection for her and so might have her baptism, but little was guaranteed, and she went into hiding in January 1943, as an apparent necessity.

\section{3. [U Boot $]$}

Rather than discussing the details that followed the loss of her job that were partially revealed in other areas of her CM/1 form, Frau Bettauer remarked on how she survived the Nazi regime until the end of the war in the second sentence of her personal statement. She "lived underground [U Boot] from 1943 until liberation," she explained (Bettauer 1950). Her loss of employment and need to go into hiding were the most important features of her experience as far as the personal statement on her application for support in 1950 was concerned. She might have thought that it would be redundant to state facts that already existed on the employment history and list of documents. It is also conceivable that she did not wish to revisit each potentially excruciating moment and so decided to limit her statement to what she saw as the most significant events in a more general way. Listing the employment history and gathering the documents may well have been stressful in themselves, if not outright traumatic.

Because going underground inherently carried an air of secrecy, it is difficult to understand what it might have been like exactly if a survivor did not explicitly recount it. Obviously, Anne Frank's time in an Amsterdam attic as recorded in her diary may quickly come to mind as an image of the realities of living in hiding. The Viennese poet Elfriede Gerstl memorialized her time underground as a young girl in the poem "Mein Lichtstrahl" ("My Shining Light"). She wrote in it that: "I mostly lay on my bed. At first, I sat in a corner of the room and got bored, because it was too dark to do anything and I was only allowed to move silently, because our apartment should be thought empty" 
(Gerstl 2017, p. 3). Similar, it seems, at least in part, to Anne Frank, but surely there had to have been a host of situations that people in hiding went through.

The term $U$ Boot, which Frau Bettauer and others used to describe going underground, is an abbreviated form of the German word Unterseeboot, meaning submarine. In his study of Jewish people who went into hiding in Berlin between 1941 and 1945, Richard N. Lutjens, Jr. calls the use of $U$ Boot for naming going underground a "Berlin colloquialism," although he notes that it was also used in Vienna (Lutjens 2019, p. xiv). He characterizes Jewish people's experiences in Berlin in hiding as highly diverse by necessity, requiring the "need for speedy adaptation, creative thinking, and problem solving in a world stuck between the ghettos and the camps" (Lutjens 2019, p. 7). Presumably, the same was true for those who went underground in Vienna, such as Frau Bettauer.

On her employment history, she also included a date range for living in hiding $(U$ Boot) from January 1943 through April 1945, offering some more specifics than her personal statement. Furthermore, it stated that she had been underground in "various places" ( $v$. Plätze) (Bettauer 1950). Hiding for more than two years and moving to different locales reveals certain aspects of her experience, while others remain opaque. Many years after the end of the Second World War and just before she passed away, Jalowicz-Simon (2014) recounted the extensive details of hiding in Berlin. In contrast, Frau Bettauer was telling her story less than five years after re-emerging from going underground. Going into hiding was a threat for the person and others who assisted. Arrest well could have meant deportation for the person discovered in hiding and prison or a concentration camp for those providing aid. Gerstl's poem speaks to an apparent Gestapo search, remembering that "sometimes hard boots came up the stairs, stopped in front of the door, and mostly they knocked too-the boots" (Gerstl 2017, p. 3).

It is possible that Frau Bettauer's baptism helped her remain in hiding until the war's end. Traude Litzka shows that in Nazi Vienna, several Jewish people were aided by the Catholic Church in different ways, including helping them go underground (Litzka 2018). In her study of Jewish people who hid in Austria between 1938 and 1945, C. Gwyn Moser argues that assimilation was key for survival because locating "shelter and a protector required good contacts with non-Jews" (Moser 1985, n.p.). This seems highly likely in the case of Frau Bettauer, since following the mass deportations of Jewish people from Vienna, there was little chance to continue to exist in the Jewish community, which had been severely diminished. Having converted, she may have already been connected to non-Jewish social networks too.

\section{Gassed in Auschwitz}

In addition to shedding some light on Frau Bettauer's life navigating the Nazi era in Vienna before and during the years the deportation of most of the city's Jewish population to their deaths took place, her personal statement described the demise of her husband. In the third sentence, she explained that he was the "son of the author Hugo Bettauer, transported to Poland from Belgium, where he was hiding in a convent." In the following line, she stated that he was "gassed in Auschwitz" (Bettauer 1950). Hence, of the first four sentences in Frau Bettauer's personal statement, she had devoted two to her experiences and two to those of her late husband. It amounted to a listing of losses: her job, her freedom, and her spouse. This made for a strong case that she had indeed been persecuted by the Nazi regime.

It is fascinating that she did not refer to her husband by name, but rather via his father, the Viennese author Hugo Bettauer. He had published the novel Die Stadt ohne Juden ("The City without Jews") in 1922, which played out the antisemitic fantasy of expelling the Jewish inhabitants of Vienna. When the city falls into extreme economic and cultural ruin, however, the authorities must invite the exiles back. Certain aspects of the book are ominous today, despite Bettauer's satirical intent, such as his description of the deportation of the remaining Jewish population of Vienna. He wrote that: "With the use of all means of transport, with the help of locomotives that were borrowed from neighboring states, with 
the cessation of every other passenger and freight transport, the last Jews were taken away in thirty gigantic trains that day" (Bettauer 1922, p. 47).

The novel was enormously popular and eventually translated into several languages, including Polish, Hungarian, English, French, Dutch, and Ladino (Bettauer 1923, 1925, 1926, 1929, 1933a, 1933b). It was adapted into a film too (Breslauer 1924). The author was also a supporter of sexual liberation and women's rights, even proclaiming the "erotic revolution" in the first issue of a lifestyles and eroticism magazine he published, a position that put him in direct conflict with the Austrian Nazis and others on the far right. He was ultimately murdered in 1925, shot to death by a young National Socialist, becoming the first victim of the Nazis in Austria (Noveck 1997). Frau Bettauer describing her late husband as the author's son underscored the sense of loss that she and her family had endured for nearly 25 years.

It is unclear how exactly she imagined Hugo Bettauer, since she married his son more than eight years after his murder. When the author was killed, she was merely sixteen years old, but it was a well-known case, so most of Vienna was aware of it. The murderer, Otto Rothstock, received a light sentence after pleading guilty by reason of insanity. He was released after less than two years in a mental asylum and continued to reside in Austria (Hall 1978). Following the Nazi annexation, he published an article celebrating it and claiming that Vienna would soon be a "city without Jews" (R[othstock] 1938, p. 2). It is difficult to determine if this genealogy of loss that Frau Bettauer established was intended more to strengthen her application or represented her way of remembering her husband and his origins. It could have contained elements of both at the same time.

Other than their marriage, the CM/1 form reveals very little about Frau Bettauer and her husband's time in Vienna. She explained that like her, he too had hidden, but in a Belgian convent. This is another fragment related to the Catholic Church, although it seems distant nonetheless from Vienna. He still clearly received aid from church members in Belgium, though we do not learn when nor under what circumstances Herr Bettauer arrived in the country and went into hiding. The following sentence in Frau Bettauer's personal statement suggests that the two had sought to emigrate to the United States together, although that would not necessarily exclude his living in Belgium, except for the additional complication of the Nazi occupation of that country too. She explained that the "affidavit did not accomplish admission into America during the war" (Bettauer 1950). Many other people of Jewish ancestry attempted to leave as well but were unable to due to varieties of reasons (see, for example, Offenberger 2017, pp. 147-49). More specifics surrounding the Bettauers' efforts are not indicated and hence are likely impossible to know.

The only other trace of Frau Bettauer's husband on the form is listed under a section for additional information. It states succinctly, "husband gassed Auschwitz 1942" (Gatte Auschwitz vergast 42) (Bettauer 1950). The booking certificate from Lisbon to New York was dated June 1941, so it seems that Herr Bettauer may have fled Vienna sometime after that. In February and March 1941, 5000 Jewish people had been deported from Austria to ghettos in Poland (Breslauer 1924). From April through September, the deportations ceased, however, and Jewish emigration moved forward, though at a drastically reduced rate. In September, Jewish people in Vienna were required to wear the Star of David on their clothing. The following month, emigration stopped altogether, and the deportations resumed (Offenberger 2017, pp. 249-50). They would continue through March 1945 (p. 279). It is hard to imagine that she could have learned of her husband's fate before she went into hiding in January 1943. Just that she had been separated from him and then went underground not knowing if he could remain secure reveals something more about the personal stresses and potential traumas she endured.

It appears that she learned several details surrounding her husband's demise sometime after the war. In a report published in a Vienna newspaper in February 1948, certain aspects of his life were outlined as were Frau Bettauer's legal efforts involving his death. It noted that Dr. Heinrich Gustav Helmut Bettauer was born in Berlin in 1899, but later became 
an Austrian citizen and resident of Vienna; he had been an author and a state insurance official, like Frau Bettauer. The report gave his last residence in Vienna and stated that his final residence in Belgium was in Maredsous in Namur Province, although it did not identify it as a monastery (Bettauer 1948, p. 5).

It was taken over by the Germans in 1942, forcing the resident monks to relocate (Abbeys 1942, p. 299). It is not known if Herr Bettauer had been discovered at the time or earlier. The newspaper report did not specify, but it did point out that he had been arrested by the Gestapo and deported from the Malines assembly camp to Auschwitz in November 1942. "Since then, there has been no news from him," it stated (Bettauer 1948, p. 5). It seemed to hold hope almost six years later that somehow he had survived Auschwitz. Information surrounding deportations was still being clarified: it is now known that Herr Bettauer was actually deported from Belgium on 24 October 1942 with 994 others aboard Transport XIV. They arrived at Auschwitz two days later and he, along with hundreds of others, was gassed to death on arrival (Yad Vashem n.d.).

Frau Bettauer was nonetheless taking steps to resolve the question of her husband's status. The newspaper report explained that she had begun a legal procedure for a declaration of his death as a follow up measure to his status as a missing person. This suggests that her postwar years also involved inquiring into the circumstances of her husband's fate. The court had ordered Herr Bettauer to appear before it or provide notice of himself in some other way. This was impossible, obviously, but illustrates the long-drawn-out efforts that family members of victims might be required to endure. After March 1948, the court was to decide on the declaration of death (Bettauer 1948, p. 5).

\section{Prevailing Antisemitism Today}

Frau Bettauer managed to obtain a position after the war as the business director of a movie theater for 1000 Schillings per month, double her salary as a state insurance official, her employment history indicates. In what must have seemed like another cruel repetition of the past, however, she explained in her personal statement that she held the job through the end of 1949 but was let go due to "prevailing antisemitism today," which was preventing her from obtaining another position as well (Bettauer 1950). Also similar to the Nazi era, she again sought to leave Austria for the United States. Although initially after liberation she had begun to pick up the pieces of her shattered life, Frau Bettauer now seemed to find herself in almost the exact same position as the immediate aftermath of the Nazi annexation.

Now, in the postwar era, her struggles with the past were evident in her personal statement. The next sentence speaks to her feelings of personal loss acutely. "The memory of my husband's murder keeps haunting me," she remarked (Bettauer 1950). Coupled with the antisemitism that she continued to experience in Austria, it was clearly a challenge to recover from her recent traumas. The case she was making for resettlement was indeed powerful.

Frau Bettauer then turned to a topic not addressed previously in the personal statement, employment history, or vital documents. "I would also like my parents to know a country where they can enjoy a peaceful retirement," and she added, "not with the racial uncertainty that prevails in Austria" (Bettauer 1950). Their activities during the Nazi era are not known. In a section for additional information, the CM/1 form indicates that they were currently living with her. It seems unlikely that they had also gone into hiding with her, but it is unclear why she omitted their experiences. One might imagine that her case for support could only have been strengthened by some indication of their apparent plight. Connected to her bid to emigrate to the United States, two other relatives, an uncle and a cousin, both residents of New York, are also listed on the CM/1 form.

Although he was not spoken of in the personal statement, Frau Bettauer's fiancé, Wilhelm Zeisel, appears on the form as a family member as well. This was another sign that she was building her life back from it having been destroyed. Discussing this situation too much may have diluted her statements about her late husband, however, so it makes 
sense that this part of her postwar existence would be muted. Herr Zeisel completed his own $\mathrm{CM} / 1$ form and the two filed their claim jointly.

His experiences before, during, and after the Nazi annexation of Austria were similar in several ways to those of Frau Bettauer. Herr Zeisel had been born Jewish in Vienna, although unlike her, he never opted for baptism. As she attended primary school, he went to secondary school during the Great War. He trained as a butcher and then worked for his parents in that trade before working on his own in it until 1938, when his business was closed following the Nazi annexation. He then worked in a brick factory for more than two years and obtained a Jewish identity card to allow him to move in and around Vienna. He eventually fell ill, however, resulting in his unemployment for several months. He briefly became a meat distributor to Jewish people in the city until again going without work for some months (Zeisel 1950).

Like Frau Bettauer, he too went into hiding, but earlier than she, beginning in May 1942. Herr Zeisel revealed in his personal statement that "several families saved my life," showing that he had necessarily moved from place to place as well. In the additional information area on the form, he wrote that his mother had passed away in 1936, his father had been deported to Theresienstadt in 1942, and his brother had been deported to Poland from France (Zeisel 1950).

More about his father and brother appeared in reports in a Vienna newspaper in 1949, similar to the situation with Herr Bettauer. The first noted that his father, Arthur Zeisel, was born in the part of the Habsburg Empire known in 1950 as Czechoslovakia. He became an Austrian citizen; he was widowed and worked as a master butcher before his deportation to Theresienstadt in June 1942 (Zeisel 1949). It is now known that from there, he was sent to the Treblinka death camp aboard Transport Bo on Train Da 83 on 19 September 1942 (Yad Vashem n.d.).

The other report explained that Herr Zeisel's brother Hans was born in Vienna and was an Austrian citizen; he was unmarried and worked as a public servant and left for Belgium at an unknown time. After the German invasion in May 1940, it noted, he fled to France and that was the last that Herr Zeisel had heard from his brother (Zeisel 1949). Today, it is known that Hans was deported from the Drancy assembly camp in France to Auschwitz aboard Train 901-20 with Transport 25 on 28 August 1942 (Yad Vashem n.d.). Like Frau Bettauer, Herr Zeisel had continued to seek his missing family members, but ultimately to little, if any, avail. It is not known if he ever learned what became of them.

The remainder of his personal statement still struck on chords similar to those of Frau Bettauer. It concluded thus: “I can't find a new job because it is almost impossible for Jews today to find an existence, too great is the antisemitism. Since I cannot find a way for my fiancée and me and my parents to start an existence here, I have to emigrate. I would like to spare all of us from reliving what we have been through in recent years" (Zeisel 1950). Since his parents had perished, his reference to "my parents," meant Frau Bettauer's parents. Like her, he too was attempting to rebuild his life as best he could and the information on his $\mathrm{CM} / 1$ form provides both insights and obscurities.

\section{Epilogue and Conclusions}

A final document in Frau Bettauer's file reveals another apparent motivation for her emigrating to the United States: an item from a German-language newspaper discussed the use of radiation as a cancer treatment. She said nothing of a sickness on her CM/1 form, but the inclusion of this piece of information suggests that it was in her interest to insert it along with other pertinent documents. The IRO official did not mention it in the summary of the interview with her either. The official wrote:

The applicant is an Austrian woman of Jewish faith. Her husband was murdered by the Nazis and she herself had to live in hiding. Although it can be considered that economically she is firmly re-established, it is felt that the applicant's sufferings and experience of anti-semitism in Austria are still active in her mind and it 
is most unlikely that she will ever be able to re-establish herself in the country where she had been persecuted ...

Following this psychological and economic assessment, she was determined eligible for resettlement by the IRO on 21 March 1950 (Bettauer 1950).

Once again, however, she did not make it to the United States. She passed away in Vienna from complications resulting from cancer in 1951. She was 42 years old. An Austrian newspaper reported in October of that year that she "recently passed away after a long and severe suffering" (Der Neue Mahnruf 1951, p. 14). It is not known if she and Herr Zeisel ever wed.

As a woman of Jewish ancestry, contending with cancer and double doses of antisemitism in Austria with the threat of death ever looming, it is a wonder that her personal statement said as much as it did. Was she confident that people of Jewish ancestry could receive financial assistance? Had women suddenly ceased being second-class citizens in Europe? Does being ill make one wish to speak? These questions notwithstanding, Frau Bettauer did testify about her experiences and her husband's murder, themselves traumatic events not necessarily easy to revisit amid other circumstances. This article shows particular impacts of the Holocaust on an Austrian Jewish woman from information taken from her CM/1 form, even though there are also gaps in what may be understood from it. Such is memory, however, so the missing pieces, the incomprehensibility, are also vital aspects of the story that reveal what it was like in part to be a survivor in the immediate postwar era and to convey specifics involved in a life in the face of the catastrophe.

Despite inevitable absences in them, the CM/1 forms operate as micro-memoirs and contain extraordinary details about victims' experiences. In a preliminary sampling of nearly one hundred of those completed in Vienna, Jewish people engaged in numerous survival strategies, which included going into hiding in Austria and in other countries, such as Belgium and Hungary, under false identities. Many Jewish people from Vienna fled to Shanghai immediately after the Nazi annexation of Austria and others departed for Palestine. Several were imprisoned in Dachau and other camps, including Auschwitz. Some recounted their trials extensively, others only briefly. In spite of all they endured, every one of these survivors returned to Vienna and applied for relief from the IRO after the war.

Whether or not they were willing or even able to speak, the words of the surviving remnant are essential for reconstructing global and local realities of the Holocaust. Focusing on these individuals allows the story to be told by those who were most directly affected and begins to counteract the mass systematic dehumanization and destruction that occurred around them and to them. In spite of the devastation, they still worked to restore their lives, their dignity, their humanity and in turn those of other victims, both the living and the dead. Grasping the machinery of genocide is important, but it is best accompanied by voices of those whom it crushed beneath it, when possible. The thousands of CM/1 forms written by survivors offer this possibility to present a more balanced and human approach.

Funding: This research received no external funding.

Data Availability Statement: The CM/1 forms may be found in the online archives of the International Tracing Service. Available online: https://collections.arolsen-archives.org/en/search/.

Conflicts of Interest: The author declares no conflict of interest.

\section{References}

Abbeys Requisitioned by Nazis. 1942. News from Belgium. New York: Belgium Information Center, vol. II, p. 299.

Bettauer, Heinrich Gustav Helmut, Dr. 1948. Wiener Zeitung. 3. February. Vienna: Oesterreichishe Staatsdruckerei, p. 5.

Bettauer, Hugo. 1922. Die Stadt ohne Juden: Ein Roman von übermorgen. Wien: Glorietta-Verlag.

Bettauer, Hugo. 1923. Miasto bez Żydów: Powieść. Translated by Ignacy Nikorowicz. Warszawa: Renaissance.

Bettauer, Hugo. 1925. Nagyváros zsidók nélkül. Translated by Elemér Halmay. Budapest: Világirodalom Kiadása.

Bettauer, Hugo. 1926. The City without Jews: A Novel of Our Time. Translated by Salomea Neumark Brainin. New York: Bloch.

Bettauer, Hugo. 1929. La ville sans juifs: Roman de moeurs viennoises. Translated by Jean Chuzeville. Paris: Albin Michel. 
Bettauer, Hugo. 1933a. De stad zonder Joden: Een roman van overmorgen. Translated by Philip Roest. Alphen a.d. Rijn: De Haan. Bettauer, Hugo. 1933b. Lah sivdad sin G'udios. n.t. Saloniko [H. mo. 1.]. Salonica: H. mo. 1.

Bettauer, Paula. 1950. CM/1 form. 3.2.1.3/80572350. ITS Digital Archives, Arolsen Archives. Available online: https: / / digitalcollections.its-arolsen.org/03020103/name/view/5079587 (accessed on 27 January 2021).

Borggräfe, Henning. 2020. Exploring Pathways of (Forced) Migration, Resettlement Structures, and Displaced Persons' Agency: Document Holdings and Research Potentials of the Arolsen Archives. Historical Social Research/Historische Sozialforschung 45: $45-68$.

Breslauer, Hans Karl. 1924. Die Stadt ohne Juden. 1. Vienna: Walterskirchen und Bittner Film Firm.

Brosch, Markus. 2012. Jüdische Kinder und LehrerInnen zwischen Hoffnung, Ausgrenzung und Deportation. VS/HS Kleine Sperlgasse 2a, 1938-1941. Diplomarbeit (Master's thesis in Teaching), Universität Wien, Vienna, Austria.

Brown-Fleming, Suzanne. 2016. Nazi Persecution and Postwar Repercussions: The International Tracing Service Archive and Holocaust Research. London: Rowman \& Littlefield.

Care and Maintenance Program. 2019. ITS Digital Archives, Arolsen Archives. Available online: https://digitalcollections.its-arolsen. org/030201 (accessed on 21 January 2021).

Central Database of Shoah Victims' Names. Yad Vashem: The World Holocaust Remembrance Center. n.d. Available online: https:/ /yvng.yadvashem.org/ (accessed on 26 October 2020).

Chopard, Thomas. 2020. Post-Holocaust Migrations from Poland to America: An Exercise in Microhistory. S:I.M.O.N. Shoah Intervention Methods Documentation 7: 13-24.

Deportations of the Austrian Jews. Dokumentationsarchiv des österreichischen Widerstandes. n.d. Available online: http:/ / en.doew. braintrust.at/chapter6.html (accessed on 23 October 2020).

Friedländer, Saul. 1997. Nazi Germany and the Jews, Vol I: The Years of Persecution, 1933-1939. New York: Harper Perennial.

Friedländer, Saul. 2008. The Years of Extermination: Nazi Germany and the Jews, 1939-1945. New York: Harper Perennial.

Gerstl, Elfriede. 2017. Mein Lichtstrahl. Der Hammer: Die Zeitung der Alten Schmiede 93: 3.

Hall, Murray G. 1978. Der Fall Bettauer. Wien: Löcker.

Huhn, Sebastian. 2020. Negotiating Resettlement in Venezuela and World War II: An Exploration. Historical Social Research/Historische Sozialforschung 45: 203-25.

Jalowicz-Simon, Marie. 2014. Untergetaucht: Eine junge Frau überlebt in Berlin 1940-1945. Frankfurt am Main: S. Fischer.

Kaplan, Marion. 1998. Between Dignity and Despair: Jewish Life in Nazi Germany. New York: Oxford University Press.

Litzka, Traude. 2018. The Church's Help for Persecuted Jews in Nazi Vienna. Translated by Gerda Joseph. Vienna: LIT Verlag.

Lutjens, Richard N., Jr. 2019. Submerged on the Surface: The Not-So-Hidden Jews of Nazi Berlin, 1941-1945. New York: Berghahn Books.

Mitteilungen des Bundesverbandes der österr. KZler, Häftling und politische Verfolgten. 1951. Der Neue Mahnruf 4: 14.

Moser, C. Gwyn. 1985. Jewish U Boote in Austria, 1938-1945. Simon Wiesenthal Center Annual 2: 52-61. Available online: http:/ / www.museumoftolerance.com/education/archives-and-reference-library/online-resources/simon-wiesenthal-centerannual-volume-2/annual-2-chapter-3.html (accessed on 23 October 2020).

Moser, Jonny. 1992. Die Anhalte- und Sammellager für Österreichische Juden. Dokumentationsarchiv des österreichischen Widerstandes Jahrbuch,71-75. Available online: https:/ / www.doew.at/cms/download/anarh/web_Jahrbuch_1992.pdf (accessed on 27 January 2021).

Noveck, Beth Simone. 1997. 1925: Hugo Bettauer's Assassination by Otto Rothstock in Vienna Marks the First Political Murder by the Nazis in Austria. In Yale Companion to Jewish Writing and Thought in German Culture, 1096-1996. Edited by Sander L. Gilman and Jack Zipes. New Haven: Yale University Press, pp. 440-47.

Offenberger, Ilana Fritz. 2017. The Jews of Nazi Vienna, 1938-1945: Rescue and Destruction. Cham: Palgrave Macmillan.

Panagiotidis, Jannis. 2020. Multiply Entangled: The Gottschee Germans between Slovenia, Austria, Germany, and North America. In German-Balkan Entangled Histories in the Twentieth Century. Edited by Mirna Zakić and Christopher A. Molnar. Pittsburg: University of Pittsburg Press, pp. 137-57.

Patterson, David. 1998. Sun Turned to Darkness: Memory and Recovery in the Holocaust Memoir. Syracuse: Syracuse University Press.

Patterson, David, Alan L. Berger, and Sarita Cargas. 2002. Encyclopedia of Holocaust Literature. Westport: Oryx Press.

Pauley, Bruce. 1992. From Prejudice to Persecution: A History of Austrian Anti-Semitism. Chapel Hill: University of North Carolina Press. R[othstock], Otto. 1938. Wien, die 'Stadt ohne Juden'. Illustrirte Kronen Zeitung, July 16, 2.

Stone, Dan. 2019. Doubly Cursed: The Sonderkommando in the Documents of the International Tracing Service. In Testimonies of Resistance: Representations of the Auschwitz-Birkenau Sonderkommando. Edited by Nicholas Chare and Dominic Williams. New York: Berghahn Books, pp. 159-81.

Zeisel, Arthur. 1949. Wiener Zeitung, January 27, 6.

Zeisel, Hans. 1949. Wiener Zeitung, April 26, 7.

Zeisel, Wilhelm. 1950. CM/1 form. 3.2.1.3/80888207. ITS Digital Archives, Arolsen Archives. Available online: https: / / digitalcollections.its-arolsen.org/03020103/name/view/5142861 (accessed on 27 January 2021). 